\title{
The Forgotten History of the Chilean Transition: Armed Resistance Against Pinochet and US Policy towards Chile in the 1980 s
}

\author{
VICTOR FIGUEROA CLARK*
}

Abstract. The history of the transition to civilian rule in Chile largely overlooks or marginalizes the role of the armed and confrontational forms of resistance to the dictatorship. This article traces the pre and post-coup history of the Left's engagement with armed forms of struggle and evaluates the effects their incorporation into the struggle against the dictatorship had upon the regime and the Reagan administration. It concludes that armed resistance was a major factor in determining US policy to Chile during the I980s, and therefore played an important role in the transition as a whole.

Keywords: Chile, dictatorship, resistance, communist, socialist, transition

The narrative of the transition to civilian rule in Chile is dominated by the view that the transition was largely an elite-level negotiation to a greater or lesser extent triggered by social mobilisations and economic crisis. The tendency is to emphasise, as President Lagos later expressed, that Pinochet was defeated 'with a pen and paper'. This perspective does not put much emphasis, if any, upon the role played by confrontational and armed forms of resistance to the regime. These activities have sometimes been labelled as terrorism, and are often portrayed as desperate acts that contributed little to the transition to civilian rule, if they did not in fact strengthen Pinochet. ${ }^{\mathrm{I}}$ By contrast this

Victor Figueroa Clark is a Guest Teacher at the London School of Economics and Political Science. Email: victorfc@gmail.com and v.r.figueroa-clar@lse.ac.uk.

* I would like to thank Mr Maurice Pinto for the support that made this research possible, Professor Arne Westad and all my interviewees, including those not cited here, for their time and patience, as well as the staff at the Reagan Library in California for their help during my research. My gratitude also to the readers and editors at the journal for their incisive and helpful comments.

${ }^{\prime}$ For examples see Rafael Otano, Nueva crónica de la transición (Santiago: LOM, 2006); William I. Robinson, Promoting Polyarchy: Globalization, US Intervention, and Hegemony (Cambridge: Cambridge University Press, 1998), p. 172; Brian Loveman, Chile: The Legacy of Hispanic Capitalism, 3rd ed. (Oxford: Oxford University Press, 2001), p. 300; 


\section{Victor Figueroa Clark}

article argues that since the violent resistance grew out of the mass mobilisations and was deployed to defend and stimulate them, it was as much a part of the resistance as were other forms of social mobilisation even if they were far more controversial.

At the time the organisations of the Left understood these methods as complementary to what were called 'mass forms of struggle': demonstrations, trade unionism, human rights and community activism and so on, with violence acting to stimulate a 'culture' of resistance, and as a 'force multiplier' for the mass struggle. Resistance could be passive (coordinated switching on of irons for example, known as 'planchatones', or closing of shops during the national strikes, mass non-payment of utility bills), or active (political muralism and graffiti, demonstrations, strikes, throwing chains over electricity cables) or confrontational (throwing petrol bombs, digging trenches, building barricades, telephone bomb threats, attacks on security forces). All the types of resistance could take offensive or defensive forms, and the confrontational and active forms could be either unarmed or armed (accompanied by the presence or use of weapons or explosives). All these forms of resistance required political preparation and organisation and had political goals (aimed at undermining the regime and bolstering the opposition's social constituency), but in addition there were more overtly 'political forms' of resistance carried out by social and political organisations such as trade unions, political parties and human rights organisations. In the case of the political parties this often meant organising active forms of resistance (such as demonstrations), which sometimes became confrontational. Broadly speaking the armed and confrontational forms of resistance targeted or defended against the coercive institutions of the state, while the political and other forms were aimed at Chilean civil society and the international community. All aimed to destabilise and eventually bring down the dictatorship, and they were increasingly used simultaneously, which makes differentiating clearly between them difficult. Therefore, the term resistance is used to denote the full spectrum of antiregime activity, and armed resistance to refer more narrowly to the armed and confrontational forms.

In both the unarmed and armed forms of resistance those involved were largely ordinary working-class people, often without much specialist preparation, and since the armed actions were often defensive and undertaken in order to support unarmed forms of mobilisation, it would seem that the

Philip Oxhorn, 'Where Did All the Protesters Go?: Popular Mobilization and the Transition to Democracy in Chile', Latin American Perspectives, 2 I: 3 (1994); Francisco E. González, Dual Transitions from Authoritarian Rule: Institutionalized Regimes in Chile and Mexico, 1970-2000, (Baltimore, MD: John Hopkins University Press, 2008); Carlos Huneeus, El régimen de Pinochet (Santiago: Editorial Sudamericana, 2000). 
distinction between the two forms has been somewhat arbitrary and artificial. ${ }^{2}$ It has also been detrimental to our understanding of the dynamics of the transition as a whole. The various forms of resistance should not be examined in isolation; the intrinsic connection between them means that if one form of confrontation was effective in helping bring about civilian rule, then all were.

The exclusive, elite-level negotiation did indeed occur, but we can only understand how and why if we examine what triggered it and take into account the factors conditioning the positions of the main actors involved in the negotiations. This article argues that an important conditioning factor, initially for the Reagan administration and the moderate opposition in Chile, and later for sectors within the regime and its support base, was the existence of an armed resistance that was linked to a vast anti-regime social mobilisation, which together seized the initiative from the regime and even came to threaten its stability, conjuring the threat of an uncontrolled transition which then determined the political pacts made between the regime, the centrist opposition and the Reagan administration. This is a history that therefore contributes to the on-going debate within the literature of democratic transitions over the extent to which democratisation is a process driven from below, arguing that mass mobilisations and violence played an important role in shaping the Chilean transition. ${ }^{3}$

In the Chilean case, measuring the effect of the resistance on the transition is somewhat complicated by the existence of a prior transition schedule planned by the regime between 1975-1980, which the Chilean process largely followed. However, this transition to a 'protected and authoritarian democracy' was intended to perpetuate and consolidate authoritarianism and the economic system it had established. ${ }^{4}$ This sham democracy would see the military initiate an honourable and orderly retirement from direct rule and put Pinochet in power until 1997, and it did not envision a role for any genuine opposition in either the transition or in the 'democracy' that would follow. 5 The rationale for this transition was that the regime had achieved the 'end of politics' in Chile. Instead, the regime's transition was subverted by economic collapse compounded by social mobilisations and a growing insurgency that created internal and external pressures. As a consequence, the regime largely abandoned its own transition, although it was buffeted into occasional openings, which meant that the transition

2 Interview with Palomo (FPMR central region commander), I 4 March 2009.

${ }^{3}$ Ruth Berins Collier, Paths Towards Democracy: The Working Class and Elites in Western Europe and South America (Cambridge: Cambridge University Press, 1999).

${ }^{4}$ Paul Drake and Iván Jaksic (eds.), The Struggle for Democracy in Chile (London: University of Nebraska Press, I 991), p. 7.

5 See Carlos Huneeus, El régimen de Pinochet, pp. 236-8, also p. 501. 
became the subject of a struggle between a moderate, US-backed opposition and a radical left-wing one. Pinochet and his regime resisted being forced to undertake a real transition until late 1986, when two things became clear, first that the Left could potentially create the conditions for their overthrow, and second that a large sector of the opposition was ready to negotiate on the regime's terms (largely, I argue, because of the first condition). These two factors were therefore intimately linked to the Left's armed resistance. Thus, although the armed resistance was not able to alter the external form or the timetable of the transition, the combination of armed resistance and social mobilisation did create the preconditions for agreement between the regime and opposition minimalists. Therefore the original superficial transition was forced to become a 'counterinsurgent project' and as a result some of its more authoritarian features were eliminated.

When the first social mobilisations occurred, soon followed by armed actions by the MIR (Movimiento de Izquierda Revolucionaria) and various isolated Communist Party (PC) cells, the regime was forced to make a choice between continuing with its planned opening or repression. Pinochet chose to crack down. The growing social mobilisations alongside the incremental growth of armed actions then stimulated Washington to re-evaluate the regime's long-term prospects. This re-evaluation took place at the same time as a fierce struggle over the administration's Latin American policy, and combined with a more general turn towards 'democracy promotion' as the most effective way of creating bipartisan support for the administration's policies and of preserving US interests in the wake of earlier policy failures in the Third World. ${ }^{6}$

Central America was initially the main focus of the Reagan administration's Latin America policy. The Somoza regime in Nicaragua had recently been swept from power by mass social mobilisations linked to an inventive and aggressive insurgency. ${ }^{7}$ Reagan's administration was deeply hostile to what it understood as evidence of Cuban-Soviet subversion on the United States' doorstep, a perception reinforced by the subsequent upsurge in the guerrilla war against the right-wing regime in El Salvador. In the weeks before Reagan was sworn in, the FMLN guerrillas there had launched a final offensive that narrowly failed to overthrow the military regime. The regime survived but a civil war raged on until 1992. As a result, for

${ }^{6}$ Howard J. Wiarda, American Foreign Policy Toward Latin America in the 8os and gos (New York: New York University Press, 1992), p. 314; Elizabeth Cohn and Michael J. Nojeim, 'Promoting Democracy' in David W. Dent (ed.), US-Latin American Policymaking: A Reference Handbook (Westport, CT: Greenwood Press, 1995), p. 462; Robinson, Promoting Polyarchy, chap. 2.

7 Donald C. Hodges, Intellectual Foundations of the Nicaraguan Revolution (Austin: University of Texas Press, 1986), pp. 246-50. 
many in the administration Central America was the Latin American crisis of the I 980 os.

But the Reagan administration soon found that the human rights situation in Chile was hobbling in its attempts to gain support for efforts in this key area and encouraged accusations that while it called for democracy in Nicaragua it supported bloodthirsty dictators in Chile and El Salvador. ${ }^{8}$ The change in policy towards Pinochet was not without its contradictions, but gradually Washington began putting increasing pressure on Pinochet, the Chilean military, the regime's right-wing social base, and the moderate opposition to find a middle ground that would preserve the regime's fundamental features within a civilian governing structure.

For two years, this approach did not seem to bear much fruit since the US found it had limited tools at its disposal and because Pinochet continued to prefer the certainties of repression to the unpredictability of a pressured transition. Then in I986 a newly united opposition agreed to bring down the regime through successive mobilisations from July onwards. As part of this the Communist Party planned two major military actions that it hoped would ensure victory. Opposition unity and the scale and violence of the July i 986 protests presaged an opposition united around a radical project that would smash the regime. US efforts to break the unity of the opposition moved into overdrive, and by August the political leadership of the moderate opposition had reneged on the plan to bring down Pinochet, covering their retreat by claiming that the social protests had failed. However, the actions planned by the Communists were already in train and despite their failure they nevertheless provided the incentive needed for Pinochet, the military top brass, and the moderate opposition to come together.

Although the armed resistance never became a full-scale insurgency, it was effective because the 'order' it undermined was important to the regime's selflegitimation and because it increased the costs of repression to such an extent that it affected the morale of the security forces. While more research using Chilean archives would be necessary to provide a complete picture, it is clear that for many in Washington, the combination of violent resistance and mass mobilisations created the spectre of a mass insurgency, which outweighed the effect of both forms of resistance taken in isolation. Without the threat posed by the combination of mass mobilisation and military resistance, I argue, there is no indication that the Reagan administration, or subsequently the Chileans, would have seen any need for a real transition.

US diplomats, politicians, businessmen, military and intelligence officers played an important role, both in public and in private, in the Chilean transition particularly between late 1984 and i988. This article disagrees with

8 Thomas Carothers, In the Name of Democracy: US Policy Toward Latin America in the Reagan Years (Oxford: University of California Press, I991), p. I60. 
perspectives that deny or limit international factors to 'significant leverage at the margin'. ${ }^{9}$ Washington was important in the Chilean transition because the actors involved in the transition understood it to be important and because it was eventually able to deploy such a broad spectrum of pressures on the regime, its supporters and opponents. One of the prime motives behind this policy was fear of the Left's insurgent mobilisation, particularly in the light of events in Central America.

Therefore, as this article explains, mass social mobilisations combined with armed resistance created the leverage used by the United States and those within the regime and the moderate opposition who sought a minimal transition to create the basis for agreement. The regime's constitution, transitional structure and timetable was then accepted as the basis for the shift to civilian rule, not because it was the only alternative, but because the moderate opposition reneged on the agreement to overthrow the regime and its institutions, and because the Communists, by this time virtually the sole political party participating in the armed resistance, chose to terminate the military dimensions of their campaign. The history laid out here therefore suggests that Elisabeth Wood's view of insurgent democratisation is partially relevant for Chile, not because the insurgents were at the negotiating table, but because of those who feared their potential. ${ }^{\circ}$

In contrast to other aspects of Chile's history in the $1980 \mathrm{os}$, the Left's resistance, including its military resistance, has been understudied and misunderstood. This is partly because it was a clandestine struggle with its own somewhat arcane theoretical basis, and partly because the overall winners of the Chilean transition, the military, the elite and the moderate opposition, had no interest in redeeming an armed resistance that had been a major threat. In hindsight, it was presented as at best pointless, and at worst criminal. Nor have the organisations of the Left done much to redeem a military history that was always controversial and failed to achieve its maximum goal.

This article therefore seeks to examine the neglected history of the Left's military policy and the role that violent forms of struggle played in the transition. It does so using archival sources from the US, interviews with Chilean participants, memoirs and previously secret internal party documents. It mainly focuses on the Chilean Communist Party as the largest and bestorganised left-wing party in Chile, the foremost organisation to develop and implement a 'military policy'. The first section explores the historical

9 See John R. Bawden 'Cutting off the Dictator: The United States Arms Embargo of the Pinochet Regime, 1974-1988', Journal of Latin American Studies, 45: 3 (2013), pp. $513-$ 43; Carlos Portales, 'External Factors and the Authoritarian Regime', in Drake and Jaksic (eds.), The Struggle for Democracy in Chile.

1 See Elisabeth Wood, Forging Democracy from Below: Insurgent Transitions in South Africa and El Salvador (Cambridge: Cambridge University Press, 2000). 
context of the Chilean Left's attitudes towards military issues and violence, the second discusses the development of the Left's 'military policy', and the third examines the resistance in relation to US policy towards Chile.

The Chilean Left, dominated by the Communist and Socialist parties, had historically sought a peaceful, unarmed road to power through alliances, elections and political organisation. ${ }^{\text {II }}$ The origins of the 'unarmed' strategy lay in the ideas and in the practice of the precursors of what became the Communist Party of Chile in 1 $922 .{ }^{12}$ After other leftist groupings founded the Chilean Socialist Party (PS) in 1933, the two parties formed their first victorious alliance with centrist Radicals, convincing large sectors Chilean society of the possibility of a peaceful, electoral, 'road to socialism'. ${ }^{13}$ Two legacies of this alliance strategy were left-wing parties that recognised themselves as parts of a greater whole, and a PC that consistently sought out alliances with the centre in order to carry out a gradual but profound series of transformations.

This approach did not go unquestioned. The i 960 s witnessed a radicalisation of politics across the world, and a generation of Latin Americans was enthused by the Cuban revolution and anti-colonial struggles that glamorised and legitimised revolutionary violence. ${ }^{14}$ In Chile, the creation of the Movimiento de Izquierda Revolucionaria (Movement of the Revolutionary Left, MIR) in 1965 crystallised this process. ${ }^{15}$ Revolutionary enthusiasm also affected the traditional 'Allendista' Left, particularly the Socialist Party, within which advocates of both the armed and peaceful roads coexisted. The Party's pro-Cuban outlook, disillusion following electoral defeats in 1958 and 1964, the political threat on the Left from the MIR, and on the Right from the Christian Democrats forced an increasing radicalisation, leading to the rise in 1967 and 1968 of the Ejercito de Liberación Nacional (Army of National Liberation, ELN) and La Organa 'insurrectional' factions of the PS. However although the influence of these groups radicalised Socialist rhetoric, in practice they did not challenge the primacy of the "unarmed road'. ${ }^{16}$

${ }^{11}$ For a more detailed account see Carmelo Furci, The Chilean Communist Party and the Road to Socialism (London: Zed, 1984); Kenneth M. Roberts, Deepening Democracy: The Modern Left and Social Movements in Chile and Peru (Stanford: Stanford University Press, 1998), p. 86.

${ }^{12}$ Luis Sicilia, Luis Emilio Recabarren: El sueño comunista (Buenos Aires: Capital Intelectual, 2007).

${ }^{13}$ See Julio César Jobet, Historia del Partido Socialista de Chile (Santiago: Ediciones Documentas, 1987).

${ }^{14}$ Patricio Z. Quiroga, El GAP: La escolta de Allende (Santiago: Aguilar, 2001), pp. 1 5-28.

is Miguel Enríquez, 'Algunos antecedentes del Movimiento de Izquierda Revolucionaria, MIR', in Miguel Enríquez y el proyecto revolucionario en Chile, ed. Pedro Naranjo et al. (Santiago: LOM, I97I).

${ }^{16}$ Quiroga, El GAP. p. 35; Interview with Patán (a member of the PS military apparatus, the ELN and Allende's GAP, and later member of the PS Central Committee) 9 Feb. 2009. 


\section{Victor Figueroa Clark}

Meanwhile, the Communists had begun to experiment with self-defence groups to defend 'the conquests of the Chilean people' in 1964 in anticipation of victory in the elections of that year, elections which the Left narrowly lost. ${ }^{17}$ Following Allende's victory in 1970 this training continued in agreement with the Socialist Party and the Cuban government, and both parties sent small groups for short courses in Cuba. ${ }^{18}$ All told, by 1973 the Communists had I,O00 members with paramilitary training, 'some of whom had some knowledge of military tactics and strategy' and 2,000 who could handle 'pistols, self defence and various forms of street fighting.' ${ }^{9}$ 'The Socialists had I,000-I,500 members with similar training. ${ }^{20}$ But while some Socialists saw themselves as the nucleus of a future armed seizure of power, the Communists did not. At the time, both parties had some 200,000 members, so the scale of these preparations remained minuscule. Their existence did not indicate an understanding or acceptance of military issues within either Party as a whole. ${ }^{21}$ Their role was to defend Party leaders and property, and in the extreme case of a coup, to fight alongside loyal units of the armed forces. These groups, along with those members assigned to collate intelligence, formed the parties' first organised experience in the military realm..$^{22}$

Only the MIR had a coherent attitude towards violence and the seizure of power prior to the coup. The MIR saw participation in electoral politics as 'reformism' and predicted that the Chilean elite together with US 'imperialism' would not allow a peaceful transition to socialism in Chile. Its task was to prepare to lead the masses in the inevitable violent struggle. As a political-military organisation the MIR was secretive, operating in public through front organisations while the leadership and core membership remained nominally underground. The MIR proper was organised in groups that contained military, political and support network subgroups, alongside a Central Force which was supposed to be the well-trained and well-armed core of the organisation. ${ }^{23}$ To this end, the MIR trained military cadres both in Chile and Cuba, yet its growth during the Popular Unity period delayed and diluted

${ }^{17}$ Luis Corvalán, Tres periodos en nuestra línea revolucionaria (Dresden: Verlag im Bild, 1982), pp. $169-70$.

18 Interview with Luis Corvalán, former General Secretary of the Chilean Communist Party (PC), i F Feb. 2007.

19 Corvalán, Tres periodos en nuestra línea revolucionaria, p. 170.

${ }^{20}$ Patricia Politzer, Altamirano (Santiago: Melquiades, 1990), p. 33.

${ }^{21}$ Interviews with 'Pedro', later a member of the PC Military Commission, 30 May 2005; 'Patán', 9 Feb. 2009.

${ }_{22}$ Carlos Toro, Memorias de Carlos Toro: la guardia muere pero no se rinda ... mierda, La vida es hoy (Santiago: Partido Comunista de Chile, 2007), p. 235.

${ }^{23}$ Miguel Enríquez, Algunos antecedentes del Movimiento de Izquierda Revolucionaria; Interview with Carmen (member of the MIR), 3 March 2009. 
the military development of the organisation. ${ }^{24}$ On the day of the coup the MIR had only 400 people in the Central Force, of whom a paltry 50 were fully equipped. ${ }^{25}$

Of all the Left's armed groups, only the MIR intended to break the hegemony of the 'unarmed road' in Chile. Meanwhile the 'military cadres' of the Communist and Socialist parties remained a defensive tool that did not challenge the predominance of the 'peaceful road', although that is not how the media portrayed them. ${ }^{26}$ The Left as a whole had no strategic intention or capacity to challenge Chile's armed forces and its policy towards the military largely consisted of seeking to neutralise and co-opt it while emphasising the military's constitutionalist tradition. ${ }^{27}$ The defence of the Popular Unity depended on the loyalty to the government of some state forces, and with the exception of Allende's bodyguards, none of the Left's armed groups resisted Allende's overthrow and none was able to prevent it. Thus, the first phase of engagement with the concept of a 'military policy' for the Left ended in abject failure. Despite this, the pre- 1973 discussion regarding forms of struggle and the armed seizure of power provided a fertile basis for the debate over the forms of resistance to the dictatorship.

\section{The Coup and the Decision to Train Military Cadres}

The coup forced the Left to begin a sustained process of self-analysis. It took place amid massive political repression, and dispersion with the imprisonment, disappearance, torture and exile of thousands of members, and the loss of many others who simply abandoned political activity. This huge change in the political and social environment altered the mentality of many leftists, prompting them to re-evaluate their views on violence. As one militant later explained,

in my case it was like, [...] 'how can it be that they killed my uncle, they had held my granddad prisoner?' - he was tortured in Concepción stadium and later died. [...] We had to learn to defend ourselves, you understand? That was it essentially, to learn how to defend ourselves. ${ }^{28}$

Many leftists therefore felt an urgent need for a defensive response to the regime's military violence. It was partly thanks to this shift that the Left as a whole began to re-assess the importance of military policy in the wake of

${ }^{24}$ Miguel Enríquez, Algunos antecedentes; Nelson Gutiérrez, 'Ecos de XXX aniversario de Miguel', available at www.archivochile.com/entrada.html.

${ }^{25}$ p. 152.

${ }^{26}$ Rolando Álvarez Vallejos, Arriba los pobres del mundo (Santiago: LOM ediciones, 201 I), pp. 84-5; Gabriel Salazar, Conversaciones con Carlos Altamirano: memorias criticas (Santiago: Debate, 20 I I), p. I 44.

${ }^{27}$ Veronica Valdivia Ortiz de Zarate, El golpe después del golpe: Leigh vs Pinochet Chile Ig6o1980 (Santiago LOM, 2003), p. 67.

${ }^{28}$ Interview with Ricardo Sanhueza, a PC military officer, I5 March 2009. 
the coup, although it would take time to come to fruition. The change was clearly dictated by the experience of the coup, and with the exception of the MIR, it was a long, contradictory, traumatic process subject to much disagreement and discussion, which eventually saw the Left incorporate new forms into its practice and identity. Meanwhile two competing strategies against the dictatorship could be discerned, a broad anti-fascist front, and armed resistance, put forward by the Unidad Popular (UP) parties and the MIR respectively. The broad front sought to include the Christian Democrats and had the aim of returning a 'renovated' democracy to Chile, a Popular Unity and Christian Democrat government. ${ }^{29}$ It was therefore a continuation of precoup policy, led by the PC. However, even while attempting to implement this political strategy the incipient roots of a new policy were developing.

These roots were nurtured by international events such as the revolutions in Portugal, Iran and Nicaragua, victory for the North in Vietnam and revolutionary insurgencies in Central America, which subsequently helped shape the perceptions of leaders and militants in the Left, pointing to possible outcomes for Chile. ${ }^{\circ}$ At the same time, in a contradictory process, social democratic ideas and Eurocommunism were influencing the thinking of some Chileans exiled in Europe, thus setting the scene for competing strategies during the 1980 s. $^{31}$

While these discussions were beginning on a theoretical level, on a practical level the Left's leaderships quickly moved to remedy what the Communist Party called the 'historic vacuum' in military policy at its I 977 Plenum. The motive had been provided by the violence of the coup, the opportunity by the Chilean Left's international dispersal and connections. The immediate rationale was that the Junta would be short-lived, and that when it fell, it would be important to have military cadres capable of being integrated into the armed forces to prevent any future coup.

Most of the training was initially provided by Cuba after a series of discussions with the Communist and Socialist leaderships during 1974 and early 1975. Fidel Castro's reasoning was simple and it chimed with that of the Left's leaders: the two parties ought to train military cadres not in order to violently confront the dictatorship, but instead to remedy their weak understanding of the military world and their influence in it. It was to ensure a future 'democratic' contingent within the Chilean armed forces, not an effort to create insurgency in Chile. Castro also appears to have agreed with the PC strategy to build a broad anti-fascist front, at least in these early

29 'Al partido y al pueblo de Chile' (October 1974) in Documentos oficiales del partido comunista de Chile emitidos después del golpe militar fascista (no place of publication, no publisher, 1975), pp. 176-7.

30 Álvarez Vallejos, Arriba los pobres del mundo, pp. 176-7.

${ }^{31}$ Salazar, Conversaciones con Carlos Altamirano: memorias críticas, pp. 409, 423. 
days, telling Volodia Teitelboim and Rodrigo Rojas from the Chilean PC in February and on I March I975, that an alliance with the Christian Democrats was necessary to defeat the Junta, and criticising the MIR's role in the UP defeat. ${ }^{32} \mathrm{He}$ also stated to them that in his view, Chile had 'no conditions for a civil war'. ${ }^{33}$ Despite this agreement, change was slow in coming and two months later, Castro reiterated his opinion that the PC ought to train military officers. 'Why have you lost so much time?' he asked, 'even if there is a political solution you will need them ... (they) will be the backbone of the new army.' 34 Once the decision was taken, the PC also approached East Germany and Bulgaria. Thanks to these programmes, by 1980 the Communist Party had over 100 members who had graduated from military academies in Cuba and East Germany, with others still undergoing training.

However, the expansion of the Communists' military work was controversial and not the product of a consensus within the PC leadership. Orlando Millas, a member of the PC's Political Commission and a sceptic regarding what was known as the 'military task' later recalled that the training of military cadres 'implied a lot, and was never properly discussed'. 35 One of the possible implications was that the training of military cadres and the creation of an 'own military force' sowed the 'seeds of a new conception of the Party, and of politics', not one necessarily consistent with the Party's traditions. ${ }^{36}$ While some perhaps foresaw future problems, the decision was pushed through because at the time neither the Cubans, nor the Chilean PC, thought of the training as preparation for violent struggle against the dictatorship, instead understanding it as a guarantee of more democratic Chilean armed forces in the future.

Meanwhile, to support their work in the new, restrictive conditions, the Communists also requested training from the USSR and others in the techniques of clandestine political organisation and resistance. These 'Military Combative Work' courses focused on organisation, but also included some weapons training. Despite these initiatives, the main emphasis in the Party's efforts to bring down the Junta remained in the political field, building

32 Castro expressed similar views in front of socialist leaders. Interview with Carlos Altamirano, 20 March 2009.

33 Rolando Álvarez Vallejos, 'La tarea de las tareas: luchar, unir, vencer. Tradición y renovación en el Partido Comunista de Chile (1965-1990)', unpubl. doctoral thesis, Universidad de Chile, 2007, p. 291. Unrecorded conversation with Jacinto Nazal, 9 Feb. 2009.

34 Álvarez Vallejos, Arriba los pobres del mundo, pp. 174-5. Álvarez had access to the Internal Archive of the Communist Party of Chile and these quotes are from documents titled 'Conversation with Fidel Castro in Havana 3 I May 1974, Hotel Habana Libre' and 'Conversations between delegations of the Communist parties of Chile and Cuba, March 1975' and 'Plan for the military training of members of the JJCC'.

35 Orlando Millas, Memorias I957-199I: una disgresión (Santiago: Ediciones ChileAmerica CESOC, i 996), p. I9I.

${ }^{36}$ Manuel Contreras quoted in Álvarez Vallejos, Arriba los pobres del mundo, p. 175. 
international solidarity to put pressure on the regime, and seeking a broad set of alliances. However, the individuals who joined the 'task' had a clear, and contradictory, idea of their role, and it was not to wait until the return to democracy. They wanted to be sent to Chile as soon as their training was over, and their assumption was that their new-found skills would be used.

Slightly later, following their April i 975 Plenum, the Socialist leadership also decided to develop a military capacity. With East German help the Party carried out a survey of its membership in exile, mainly to help in its reorganisation, but also to gauge members' willingness and ability to join the military task. ${ }^{37}$ Two former ELN members, Rolando Calderón and Carlos Gómez, were appointed to the leadership of the 'Technical Commission' in charge of the Party's military work. ${ }^{38}$ Officer training was then requested of the Cubans and East Germans, and subsequently the Soviets were asked to provide a nine-month resistance skills course to a group of leadership cadres. $^{39}$ By the beginning of 1978, Carlos Altamirano, the PS General Secretary, was able to tell Erich Honecker in Berlin that alongside the 1,200 socialists that had been given either political or paramilitary training in the GDR, 'Fifty to sixty comrades have been given military training over these years in Cuba and the USSR.' ${ }^{\circ}$ According to one Socialist military cadre, and later Central Committee member, the idea was

to create a backbone for the leadership of part of the existing [state] army, or [the leadership] of a new army of the masses. But we needed a command structure with the necessary knowledge regarding military planning, organisation and military work in general. With people who really knew what the general laws of modern combat were, in other words - military art. ${ }^{\mathrm{I}}$

As with the PC, despite the expansion of military training, the reality was that it was still a rather minor concern. Much more importance was given to communications between the Party inside Chile and in exile, and establishing political training for the Party cadres to remedy the ideological weaknesses that were identified as a significant failure in the wake of the coup. ${ }^{42}$ The Party's concentration on political struggle, and the continued failure to develop an integral, party-wide military strategy, led to the creation of a military 'own force' that, like that of the communists', was convinced of its role in the overthrow of the dictatorship while the leadership continued to see it as

37 Interviews with Carlos Altamirano; Patán.

${ }^{38}$ Interview with Patán.

39 Interview with Patán; Bukovsky documents: ct38-76, available at http://www.bukovskyarchives.net/pdfs/terr-wd/terr-wd-rus.html\#7.4.

40 'Los documentos secretos de Honecker sobre Chile', Revista Qué Pasa, i 6 May 1998.

${ }^{41}$ Interview with Patán.

42 PS, 'March Document' March 1974, p. 24, available at www.socialismo-chileno.org/PS/ index.php?option $=$ com_content $\&$ task $=$ view $\&$ id $=859$ \&Itemid $=52$. 
the seed of a new military 'of socialist positions'. ${ }^{43}$ This confusion was confirmed by Oscar de la Fuente, a then-member of the PS Central Committee who recalled "where [did] the military training fit in? What strategy [did] it fit into? I can answer for the PS - it [fitted] nowhere.' 44 As time went on and ideological debates consumed the leadership, the military training continued although with little clarity as to its purpose.

Meanwhile the MIR's military work was developing along slightly different lines. In the wake of the coup, it set about trying to develop armed resistance to the coup, but the scale of the repression and its smaller social base made it impossible to do so successfully. In fact, Andrés Pascal Allende, a member of the MIR leadership, later recalled that 'all that small military apparatus we had became more of a hindrance than a help, because you had to be hiding and looking after the weapons and we had no capability of reacting militarily to the government.' 45 The MIR was therefore unable to capitalise on the overthrow of Allende.

The killing of MIR leader Miguel Enríquez in October 1974 forced its surviving leadership into exile where it sought to regroup and develop a new strategy to confront the 'gorilla' dictatorship. The MIR leadership decided to begin systematic training of its people in different military and clandestine specialisms with a view to an eventual return to Chile. ${ }^{46}$ It is likely that up to a thousand miristas were subsequently provided with some kind of training, a significant proportion of the post-coup membership of about 4,000.47 Lacking the international connections of the UP parties, the MIR relied mainly on Cuba for training. However, to avoid exacerbating problems between the various groups of Chileans, the Cubans refused to offer the MIR regular officer training, instead offering 'special' training in guerrilla warfare, urban operations and clandestine work. ${ }^{48}$ While the Cuban leadership had told Communist and Socialist leaders that there were no conditions for armed resistance against Pinochet, it is likely that they provided this training to the MIR because they knew it was committed to such a course of action regardless of its hopes of success. Furthermore, their long-standing friendship with the MIR's leaders meant that they could not abandon them. If the MIR were successful nothing would be lost in any case.

${ }^{43}$ Resolutions of the Sept. 1976 PS Plenum, p. I I.

${ }_{44}$ Interview with Óscar de la Fuente, 20 March 2009.

${ }^{45}$ Interview with Andrés Pascal Allende (of the MIR political commission) 5 March 2009.

${ }^{46}$ Enérico García Concha, Todos los días de la vida: recuerdos de un militante del MIR chileno (Santiago: Cuarto Propio, 2010), p. I6r. García was in charge of the MIR's training in Cuba from January i 975 .

47 Two interviewed sources, Andrés Pascal Allende and Carlos Zarricueta, mention I,000 Miristas trained, and Pablo Buenaventura mentions 400 in 'Territorios Fragmentados', p. I35, available at Archivo Chile and at www.archivochile.com/Derechos_humanos/ testimo/hhddtestimooo26.pdf.

${ }^{48}$ Interview with Andrés Pascal Allende. 
In 1978, the MIR initiated a 'Policy of Return' aimed at re-infiltrating its members into Chile to develop armed resistance to the dictatorship. To this end, the organisation undertook a survey of its members in exile, finding that in the wake of the repression the organisation had fragmented, and was divided on the issue. ${ }^{49}$ It was a difficult decision, as one mirista later wrote,

I toss and turn $[\ldots]$ without being able to sleep: I am leaving first thing [...]. I know that I can die at any time or be imprisoned again, but I know that it is the right thing, or at least I feel it to be necessary, imperative, a moral duty to be in the front line of the struggle. ${ }^{50}$

\section{Policies of Resistance}

By the end of the 1970s, the scene was set for a change in the policies of the traditional Left, although it would be some time before this percolated through to their actions within Chile. From the mid- to late I970s, the parties were engaged in a process of training cadres, re-establishing networks and logistics in Chile, and developing a mass international solidarity movement which covered both the socialist and western world. Then in 1977, Pinochet outlined the future institutionalisation of his regime, and the Left redoubled efforts to reach agreement with the Christian Democrats. The Communist Party published a 'Democratic Project' seeking to lure the PDC (Partido Demócrata Cristiano) into a broad alliance by volunteering, depending on the circumstances, to exclude itself from a post-dictatorship government. Although the PDC agreed on many issues they rejected an overarching alliance. Then from 1978 the Left began to observe an increasing militancy in popular attitudes towards the regime. ${ }^{51}$ The first popular mobilisations and labour strikes following the coup combined with increased militancy among the left-wing rank-and-file to be rather optimistically taken as evidence of a new mood in society as a whole. Alongside international events, they contributed to a feeling that change could be just around the corner if only something new could be brought to the struggle.

The first organisation to bring something new to the struggle was the MIR. In a first phase, the MIR sought to protect existing forms of rebellion while stimulating new acts of resistance to break down the aura of invincibility around the dictatorship. The aim was to introduce and eventually 'generalise' revolutionary violence against the dictatorship, leading to a full-spectrum

49 Buenaventura, Pablo 'Territorios fragmentados', p. I 35.

so Guillermo Rodríguez, Destacamiento miliciano José Bordaz (Santiago: CES DPV, 2008), p. 65.

51 Gladys Marín, La vida es hoy (La Habana: Casa Editora Abril, 2004), p. 146; Comité Memoria Neltume, Guerrilla en Neltume: una historia de lucha y resistencia en el sur chileno (Santiago: LOM Ediciones, 2003), p. 91; Luis Jerez, Ilusiones y quebrantos (desde la memoria de un militante socialista) (Santiago: Forja, 2007), p. 354. 
confrontation and revolutionary victory. ${ }^{52}$ The MIR's plans envisioned its creation of defensive ad hoc territorial militias, stimulating an active political opposition united around resistance to the regime, and targeted spectacular armed actions by full-time revolutionaries. To stimulate resistance further and provide the nucleus of the MIR's 'own force', a rural insurgency was planned and in early 1980 a small group of miristas began working to establish a guerrilla foco near Neltume, in Chile's forested south, reconnoitring the region and building supply caches to prepare for the later deployment of a guerrilla column. However, part way through their preparations the unarmed miristas were discovered, and after evading 2,000 army troops for two months their unit was destroyed. 53 The MIR's ambitious plans then had to be downscaled, but despite this their armed resistance was a shock to the regime.

The MIR's early operations came at the same time as the economic system established by the regime was collapsing. It sought to protect and stimulate the first demonstrations of mass discontent. Operations included symbolic actions such as the March I 980 seizure of Chile's original flag of independence and bank robberies to help fund their activities. The MIR also targeted military officials, killing the army's Chief of Intelligence in 198I. However, the MIR's 1983 assassination of the military Intendant of Santiago in response to the killings of unarmed demonstrators provoked severe repression. The MIR's structures were dependent on a small base of activists and as a result they were soon eliminated. Yet the MIR's armed resistance was the first effort to challenge the regime on its own terms and it prompted Pinochet to make fighting 'terrorism' his priority, undermining the liberalisers in the regime. ${ }^{54}$ The MIR's armed resistance was the first forced choice laid on the dictatorship.

Meanwhile other groups, including some Communists, began acting largely on their own initiative to carry out a variety of 'daring actions' such as pamphleteering, spreading rumours and painting slogans on walls. 55 The desire to fight back was then developed into policy proposals during 1979 and 1980 by the PC's leadership inside Chile, and by the Party's military commission in exile. Initially, these proposals were for the use of 'audacious actions' in order to lift the morale of the masses, and during I980 and I98 I the Party set up 'Small Groups' or 'Grupos Cero' that carried out sabotage actions

52 Neltume, Guerrilla en Neltume, p. 53, pp. 8 I -4 .

${ }^{53}$ For a description of the Neltume events, including soldiers' testimonies, see Guerrilla en Neltume.

54 Carlos Huneeus, El régimen de Pinochet, p. 507.

5s PC internal leadership report cited in Álvarez Vallejos, Arriba los pobres del mundo, pp. 1989; also Luis Corvalán, De lo vivido y lo peleado, 2nd ed. (Santiago: LOM Ediciones, 1999), pp. $213-14$. 
like the bombing that blacked-out the February 198 I Viña del Mar music festival to achieve this goal.

While the Communists noted that their 'audacious actions' (and presumably the MIR's) were improving the mood among the masses, the Socialist Party was disintegrating as a result of disagreements over whether it ought to seek to emulate the Communist Party or become more like Europe's social democrats. ${ }^{56}$ Some Socialists sought to implement a policy similar to the Communists' 'policy of rebellion', while another sector gradually abandoned revolutionary politics, and eventually allied with the Christian Democrats. ${ }^{57}$ The disagreements crippled the coherent application of any policy inside Chile.

\section{The Policy of Mass Popular Rebellion}

Although virtually the entire PC leadership acknowledged that changes needed to be made, there was no unanimity on what forms the new policy ought to take. The use of violence was not the PC way of doing things, and for many it risked alienating the Party from both the masses and the rest of Chile's democratic forces. However, the need to up the ante became more urgent following the September 1980 referendum to institutionalise and perpetuate the dictatorship, and amid growing fears that Chile's Christian Democrats might follow in the footsteps of their Salvadorean counterparts, and become co-opted by the military regime. In three speeches in September, November and December 1980, Luis Corvalán the PC General Secretary, outlined the Party's new attitude: 'Pinochet intends [...] to remain a dictator imposed and sustained by bayonets for a total of 23 and a half years', therefore, Corvalán continued, 'it is fascism that creates a situation, faced by which, the people have no other option but to turn to all the means within their reach, to all the forms of struggle that may help them, including acute violence, in order to defend their right to bread, liberty and life.' 58 Similar views were expressed by the PC's allies, with Clodomiro Almeyda the leader of one socialist faction saying that 'the hopes of aperture are now abandoned' and Anselmo Sulme, the leader of the Chilean Radicals stating that 'the people has won its right to rebellion'.59 The Party's new position was also greeted warmly by the MIR.

However, what these speeches would mean in practice was unclear. To some the Party had finally defined a new line; for others it meant adaptations within

${ }^{56}$ Eduardo Gutiérrez, Ciudades en las sombras (una historia no oficial del Partido Socialista de Chile (1970-1990) (Santiago: Editare, 2010), p. I 23.

57 For a description of this process see Jorge Arrate and Eduardo Rojas, Memoria de la izquierda chilena, tomo II (1970-2000) (Santiago: Ediciones B, 2003).

${ }^{8}$ Corvalán, Tres periodos en nuestra linea revolucionaria, p. 237.

59 Corvalán, De lo vivido y lo peleado, pp. 275-6. 
it, the addition of some pizazz to an old recipe. The confusion had its roots in the debates over the new policy while the Party was preparing for the Plenum of its Central Committee to be held in May $198 \mathrm{I}$ in the East German town of Cottbus. The internal leadership prepared a document known as 'La Pauta' (The Roadmap), which proposed audacious actions and the use of violence, building towards mass insurrection which would eventually overthrow the dictatorship. The language and the content of this report was seen by many within the PC as 'ultraleftist', but in some ways it was a reflection of a new reality in Chile, with one demonstrator recalling:

We got used to confronting the dictatorship from the age of $\mathrm{I} 2$ or I 3 . After a while we no longer feared the police or the armed forces [...] Some of us got to operate in the first demonstrations, before the frente patriótico, without a MIR of any strength, without any socialists or communists convinced of the need to use arms - the people outgrew the organisations and forced them to catch up. ${ }^{60}$

However to many Communists this confrontational attitude was controversial. The discussions were so severe that according to Gladys Marín, then leader of the PC's leadership inside Chile, a congress planned for 1982 was put off for fear it might split the Party. ${ }^{61}$ As a result the leadership compromised and the Política de rebelión popular de masas (Policy of Mass Popular Rebellion, PRPM) was born. This officially incorporated some military elements into the Party's practice, and sanctioned a variety of other forms of active resistance. The Party leadership debated the weight that 'acute violence' and acts of resistance ought to carry in relation to mass struggle, as well as the role of the 'own military force', but the goal of the policy remained the overthrow of the regime, a constituent assembly and elections. The leadership clearly hoped to create a new power bloc for change that would include much of the PDC. ${ }^{62}$ However the compromise on the forms of struggle at top level allowed Party members to understand the policy in different ways, some as a continuity of mass politics with some new elements, others as a complete shift in the Party line. These disagreements were never adequately dealt with and prevented the PRPM from being applied coherently.

Meanwhile, the Party's officer-trained military cadres continued to graduate from socialist military academies. In 1980, following Corvalán's declarations, some members began to receive training in the USSR in a variety of military and political courses tailored to the Chilean situation. ${ }^{63}$ The Soviets also

${ }^{60}$ Interview with Alfonso Castillo, 23 July 2009.

${ }^{61}$ Claudia Korol, Gladys Marin: conversaciones con Claudia Korol (Santiago: Ediciones America Libre, 2004), p. 47.

${ }^{62}$ Tomás Moulian and Isabel Torres '¿Continuidad o cambio en la línea política del Partido Comunista de Chile?', in El partido comunista en Chile: una historia presente, ed. Augusto Varas et al. (Santiago: Catalonia, 2010), pp. 300-1.

${ }^{63}$ Interview with Igor Ribalkin (one of the CPSU International Department officials charged with attending to the Chilean Communist Party), 3 Oct. 2007. 
assisted top PC leaders in returning to Chile, providing Corvalán (a wellknown public figure) with plastic surgery, and helping in the development of documentation and in the logistics of their return. By 1983, much of the Party's top leadership was operating in Chile while pretending to be abroad. ${ }^{64}$ The re-articulation of the Party leadership, the development of a new policy towards the dictatorship and the existence of trained military cadres all contributed to the next step in the Communists' struggle, the formation of the Manuel Rodríguez Patriotic Front (FPMR).

Once the Party had taken its first steps towards accepting the use of some forms of violence, its military commission had begun sketching out the forms that this might take. Based on earlier work in the military sphere the commission envisioned the creation of a three-part 'revolutionary military force' made up of the Party's own military force, winning over sectors of the Chilean army, and creating units of armed popular militia. ${ }^{65}$ The commission recognised that Chile did not have a tradition of armed resistance, and it therefore proposed a scaled increase in the militancy of the actions. The Party's sophistication in this area increased with input from its military professionals in Cuba and Nicaragua, the analysis teams in the GDR, and the work of the military commission itself, all of which looked to build on the military experiences of other Communist Parties. ${ }^{66}$

The Party's 'own force' took its name from a hero of Chile's wars of independence, and a renowned guerrilla fighter, Manuel Rodríguez. The decision to create a separate military apparatus not clearly identified with the Communist Party was taken for several reasons. It allowed for independent groups and individuals to participate; indeed the 'Frente' did incorporate members of other political groups and many without previous political affiliation. Not openly associating the FPMR with the Party shielded its leaders from repression following the Frente's actions and initially confused the regime's intelligence services. However, it also allowed the leadership to fudge the issue of whether or not the 'military task' was the responsibility of the Party as a whole although the Frente's leadership and the majority of its members were communists and the organisation took its orders from the Communist Party's political commission. The creation of a separate military apparatus was a risky gambit; historical experience from around the world showed that this tended to cause splits. ${ }^{67}$ But, the apparatus structure allowed a concentration of military expertise, and in a Party that was divided over the issue of armed struggle at every possible level, the alternative,

${ }^{64}$ Corvalán, De lo vivido y lo peleado, p. 223.

${ }_{65}$ Military commission document cited in Álvarez Vallejos, Arriba los pobres del mundo, p. 195.

${ }^{66}$ Interview with Pedro (of the PC military commission), I 3 Feb. 2007.

${ }^{67}$ Interview with Germán (a PC military officer and later member of the FPMR leadership). He recounts telling Shafik Handal, the leader of the El Salvadorean Communist Party about the way the PC was developing its military capacity. 'You guys will split' was the response, 3 Feb. 2007. 
the introduction of military elements of struggle into the activity of the Party as a whole, was impossible in the short term. The 1984 introduction of Military Work in the Masses was an effort to rectify this, but although this work did not just involve what would be considered overtly military forms, those charged with its development encountered serious difficulties. ${ }^{68}$ At the same time the Party also introduced Work Towards the Army. ${ }^{69}$ Under the command of the military commission, these were the instruments of the Communists' military policy charged with contributing to the end of the dictatorship.

\section{Resistance, Pinochet and the US}

The three elements of the PC military policy expanded rapidly during the relatively short period of their development (from 1980 to 1983 in incipient form, and from 1983 to 1987 in a more systematised way). They were closely linked to the social mobilisations against the regime, and they helped to drive the transition process, in particular through their effect on US perceptions of the situation in Chile. This can be seen in the stages that can be observed in the Reagan administration's Chile policy after 198I. While this policy was shaped by a series of domestic factors linked to the administration's Central America policies, a connection to the increasing levels of social mobilisation and armed resistance can also be discerned.

Upon coming into office and in the absence of any social mobilisation or active resistance to the Pinochet regime, Reagan normalised relations, saying in an early NSC meeting that the US needed to 'change the attitude' of its diplomatic corps and 'should re-establish relations with countries like Chile'. ${ }^{\circ}$ However, this rapprochement was soon undermined by the contradictory pressures of the administration's Central American goals and Pinochet's repressive reaction to social mobilisations in Chile..$^{71}$ Pinochet's hard-line response opened the Reagan administration up to criticism for the hypocrisy of its attitude towards Chile in comparison with Nicaragua, and for its support of dictators and lack of concern for democracy and human rights in general. Therefore pressure grew to force the Pinochet regime to improve human rights, and the White House was obliged to begin privately urging Pinochet to make improvements. ${ }^{72}$ However, this second approach

${ }^{68}$ Luis Rojas Nuñez, De la rebelión popular a la sublevación imaginada (Santiago: LOM 201 I), p. 24.

69 Ibid., p. 22.

${ }^{70}$ Minutes of NSC meeting, 6 Feb. I98 I, Box 91 282 [Caribbean basin and Poland], Executive Secretariat Meeting files, Ronald Reagan Library (hereafter RRL).

${ }^{71}$ Peter Kornbluh, The Pinochet File (New York: New Press, 2003), p. 4 I 2.

${ }^{72}$ Morris Morley and Chris McGillion 'Soldiering On: The Reagan Administration and Redemocratisation in Chile 1983-1986', Bulletin of Latin American Research, 25: I (2006), pp. I-26. 
stumbled once Chile's economic recession worsened and the regime was forced to face its first expressions of mass opposition and violent resistance. Pinochet's imposition of a state of siege and his intransigent stance in incipient negotiations with the centrist opposition made it impossible for Washington to argue human rights had improved and threatened to radicalise the pro-transition opposition.

The Reagan administration was then caught between wanting to support Pinochet as an ideological ally and needing to improve its human rights reputation and pursue its Central American policy. Yet the adoption of a unified administration 'line' on Pinochet was complicated because of disagreements within the administration over the correct policy to follow. This was partly because the threat to the regime was as yet minor, as a 1983 intelligence report stated, the Left was 'likely to be a peripheral actor' for the foreseeable future, and partly because the administration, according to Vernon Walters, could not 'overlook our experience in changing devils we know for a Castro, the Sandinistas or a Khomeini' ${ }^{73}$ Without a tangible threat to the regime, it seemed risky to force a transition. Without internal agreement on how to deal with Chile and without either a clear threat from the Left or an acceptable replacement for Pinochet, the Reagan administration largely continued with its quiet diplomacy.

That clear threat came with the birth of the FPMR, announced on I4 December 1983 with the coordinated destruction of several electricity pylons that plunged Santiago into darkness. Other actions soon followed, including attacking the offices and barracks of the hated CNI (Central Nacional de Informaciones) secret service. Chile was subjected to a severe economic crisis after $198 \mathrm{I}$, and the opposition, which had been trying to organise mass mobilisations, was pleasantly surprised by the long series of massive demonstrations that shook Chile for the next three years. ${ }^{74}$ The effervescence of mass opposition hid some of the deeper social changes that had taken place since 1973 and caused an optimistic view of the overall situation among the Left, but nevertheless the FPMR was launched in favourable circumstances.

The Party's 'military work' developed in tandem with the increasing social mobilisations and as the commander of the TMM (Trabajo Militar de Masas) later explained, was designed not 'to seek confrontation for its own sake. [...] The policy was to destabilise, sabotage - that was the political concept behind it - defence, propaganda and audacious actions.' 75 Party and FPMR militants helped shantytown dwellers plan the defence of their neighbourhoods, and develop homemade weaponry. The FPMR also cut railway lines, blew up

73 FOIA, CIA report, 'Prospects for Chile', 2 Sept. 1983; Memo 'US Policy Toward Chile' to ARA from Vernon Walters, 2 I Nov. 1984.

${ }^{74}$ Loveman, Chile, pp. 294-7.

${ }^{75}$ Interview with Salvador (Commander of the Party's mass military work), I I Dec. 2007. 
bridges, downed electricity pylons, took metro stations in order to distribute political materials, placed 'noise bombs' by the offices of transnational companies and the US embassy, sabotaged gas pipelines, carried out simultaneous blackouts across much of Chile, attacked police stations in poor areas, stole trucks carrying food, and distributed their contents in poor urban areas, carried out bank robberies and ambushes against police vehicles. ${ }^{76}$ Later the FPMR also placed bomb threats against the shopping centres where the Chilean elite socialised and attacked Tobalaba airport, claiming to destroy several military helicopters including Pinochet's personal aircraft. 77 Together these actions not only disturbed the tranquillity of the elite, they also undermined the sense of military omnipotence, both of which were important to the regime's supporters. While labelled as 'terrorism' in the Chilean press, according to a US intelligence report from 1984, the attacks were designed to 'cause maximum property damage but minimum personal [sic] injuries', which was in accordance with the PC's limited objective of destabilising the regime. $7^{8}$

For some within the Party, the military policy threatened ever more subjective understandings of events leading to 'voluntarism', but these views were undermined by the growth of the social mobilisations in combination with the PRPM. A detailed analysis of this growth carried out by the interior leadership team of the Party towards the end of 1984 judged that a 'pre-revolutionary situation' was developing, where 'subjective factors' became hugely important. This along with a series of other factors prompted the Party to adopt a maximalist interpretation of the PRPM. First, Pinochet had entered into a dispute with more moderate elements within the regime as well as with a Reagan administration that was keen for Chile to 'democratise'. Second, they assumed the economic crisis would continue, and would prompt escalating popular mobilisations. The Party also optimistically identified evidence of divisions within the military as 'an extremely important loss of cohesion' and incipient proof of a democratic sector within the armed forces. The PC's military efforts were thus being applied successfully. Not everyone agreed, but taken together these factors seemed to indicate the route to a rapid overthrow of the dictatorship, unity of the opposition, increased mass mobilisation, continued development of the military elements of the Party's policy, alongside efforts to provoke division in the military. ${ }^{79}$

${ }^{76}$ According to the Chilean embassy in Washington there were 1,889 'terrorist attacks' in Chile between Aug. 1983 and Sept. 1984, with a success rate increasing to 92 per cent. Update on Chile, Dec. 1984, Latin American Affairs Directorate (LAAD), NSC Records, Folder: Chile 1987, RRL.

77 FPMR, Manuel cabalga de nuevo (Santiago: n/a, 1986), pp. I46-53.

${ }^{78}$ FOIA, NID, 23 Aug. 1984.

79 A PC 'Political Report' from December 1985 cited in Rojas Nuñez, De la rebelión popular a la sublevación imaginada, pp. 45-7 and pp. 58-60. 


\section{I 2 Victor Figueroa Clark}

Therefore, following the December 1984 Plenum (known as the 1985 Plenum), the Party leadership appointed a group to develop the plans for a national uprising. This plan was envisioned as:

a mass revolt or uprising that involves the whole population, the greater part of political and social forces, and hopefully also an anti-dictatorial part of the armed forces. It is about achieving a state of generalised rebellion that achieves the real paralysation of the country, popular revolts in the main urban centres, with firm participation by the industrial proletariat, students, middle strata and the peasantry. Such actions should be strengthened by blows supporting the paralysation which helps to accelerate the political and moral breakdown of the repressive forces. The culmination of this process should be the seizure by the masses of the main political centres of the country. ${ }^{80}$

However, the emphasis remained on political unity and mass mobilisation and throughout 1985 the Party sought to build the political alliances necessary to bring together 'the greater part' of Chile's political and social forces. Meanwhile, the Party and the FPMR expanded their military activity in support of social mobilisations, leading a June 1986 CIA report to note that the highest number of bombings in the world had occurred in Chile during $1985 .{ }^{81}$ While this increase in military activity was important, it was far from taking over from the political forms of struggle, which Gladys Marín, the leader of the PC in Chile later called a 'war of houses, of meetings in bedrooms' in the effort to build organisation and unity. ${ }^{82}$

Meanwhile Washington had been following the increase in mass protests, the establishment of the FPMR, and the subsequent increase in anti-regime violence with concern, sparking fierce arguments over how to balance sympathy for Pinochet with support for a transition. ${ }^{83}$ This debate took place within a broader discussion over the adoption of democracy promotion as an effective foreign policy tool. ${ }^{84}$ It was clear that the protests would not fade away and therefore Pinochet was faced with two options; to initiate a transition to civilian rule or use violence to silence protests. He chose the latter option. Pinochet's iron fist policies alienated and discouraged even those opposition minimalists who merely wanted a transition to civilian rule, encouraging even them to support rebellion since as a CIA report noted in July 1984, Pinochet seemed to make changes 'only under strong duress'. ${ }^{8}$ The spectre of this 'moderate' opposition uniting with the 'radicals' loomed. The re-imposition of the state of siege at the end of 1984 finally

${ }^{80}$ Definition from the PC 'Report to the Central Committee of the Communist Party of Chile, January 1985', cited in Álvarez Vallejos, Arriba los pobres del mundo, p. 22 I.

${ }^{81}$ FOIA, 'Terrorism Review', June 1986.

${ }^{82}$ Korol, Gladys Marin, p. 92.

${ }^{83}$ Carothers, In the Name of Democracy, p. I 53.

${ }^{84}$ Wiarda, American Foreign Policy, p. 3 I 4; Cohn and Nojeim, 'Promoting Democracy', p. 46 I.

${ }^{85}$ FOIA, CIA Report 'Pinochet under Pressure', July 1984. 
convinced doubters in Washington of the need for a transition and the Reagan administration began pressuring Pinochet to initiate a one before he made 'conditions ripe for another Nicaragua'. ${ }^{86}$ The administration argued that if Pinochet only dealt with the 'terrorist threat without simultaneously progressing to a political transition' it would 'let the Communists define the rules of the game. ${ }^{87}$ The implication of subsequent policy was that Pinochet had no real interest in a transition and would be subsequently unable to deal with the resulting 'terrorist threat'. With some see-sawing, the Reagan administration gradually began to move towards a policy of pressuring the moderate opposition to abandon its rejection of the 1980 Constitution, as well as leaning on the Chilean military to understand the desirability of a stable transition, encouraging allies and countries close to the regime and opposition to use 'whatever leverage they may have' to do the same. ${ }^{88}$

In a signal of this shift, in November I 985 the United States replaced its proregime ambassador with Harry Barnes, who was charged with carrying out much of the groundwork for the new policy. ${ }^{89}$ Later, through institutions like the National Endowment for Democracy and AID, the United States began to actively work to create a 'moderate' political consensus in the political elite, as well as counter left-wing influence in the trade unions and among the poor. ${ }^{9}$ Washington also applied measured economic pressures in international financial institutions to encourage the regime to hand power to a civilian coalition (without Communists). ${ }^{91}$ This policy was complemented by efforts to increase contacts with the Junta and military officers. These soon bore fruit. By I 986 some members of the Junta were voicing their support for the transition and one senior Air Force officer was telling US officials that the Air Force, Navy and the Carabineros all supported a 'reasonable and peaceful transition to democracy'. ${ }^{92}$ The main barrier was Pinochet himself.

Meanwhile, the FPMR's increasing sophistication and capacity became evident in actions like the rescue of a seriously wounded fighter from a military hospital, an attack on the Army's military academy, and a series of abductions of regime officials. Other actions cut electricity to coal mines, affecting industrial production. The Communist Party's size and organisation allowed it to create the logistical networks necessary to support and coordinate a high

${ }^{86}$ State Department sources quoted in 'Ominous Scenario in Chile', Washington Times, 7 Dec. 1984.

${ }^{87}$ NSC Paper from 1984 on 'US Policy Towards Chile 1987', Folder Chile 1987 [02/15/ 1985-02/21/1985], Box 91172, LAAD, NSC Records, RRL.

88 Ibid.; Carothers, In the Name of Democracy, p. I 54.

${ }^{89}$ Carothers, p. I55.

90 Robinson, Promoting Polyarchy, pp. 177-89; Alan Angell 'Unions and Workers in Chile during the 1980s' in Drake and Jaksic, The Struggle for Democracy, p. I 98.

${ }^{91}$ Ibid., p.I70.

92 Memo, Tillman to Pointdexter re Luncheon, i6 May 1986, Folder Chile 1986 (I), Box 9 I I 8 I, LAAD, NSC Records, RRL. 


\section{I 4 Victor Figueroa Clark}

level of activity, and its international contacts in Latin America and beyond also helped build support networks in neighbouring countries. ${ }^{93}$ At this point, the resistance seemed invulnerable and it was destabilising a regime that based its self-legitimation in large part upon the provision of stability built on fear and obedience.

Then in January I 986 the Party's political efforts also bore fruit as the opposition came together in the broadest coalition yet achieved, the Asamblea de la Civilidad (AC), a body bringing together social movements and the political opposition, which included the Communists, their allies and the moderate opposition led by the Christian Democrats. The AC planned a series of national protests for 1986 that would culminate in an indefinite national strike in October that year, and in April it presented its 'Demand for Chile' the rejection of which would trigger the planned protests. ${ }^{94}$ For the first time, the declared goal of the mobilisations was to overthrow Pinochet, the establishment of a constituent assembly, and the creation of a new democracy. Meanwhile, in early 1986, a CIA intelligence report on the Chilean Communist Party stated that 'a substantial threat to political stability in Chile could develop over the medium to long term', sustaining that an allout insurgency could develop that might lead to 'civil war on the Central America pattern' whereby the communists would 'stand a good chance of reaching power'.95 A month later, a CIA terrorism review confirmed that the PC was making 'considerable headway', and while this report denied any imminent threat to the regime it did speculate that the PC's resistance was following a timetable heading towards 'all-out insurrection' in three to four years. At the same time the report highlighted the worrying admission by PDC leaders that there was substantial grassroots cooperation with the communists. ${ }^{96}$ In light of the creation of the AC, there was clear potential for this cooperation to transform the social base of the resistance and lead to 'full-blown insurgency' with dire consequences for the regime and the type of transition the Reagan administration desired. 97 Thus it was not the social mobilisations per se that were worrying US officials, but their insurrectionary potential, which would be intensified by regime intransigence, and could lead to an overthrow such had occurred in Nicaragua or Iran. The

93 Interview with Carlos (the officer responsible for the FPMR's external logistics), 24 Sept. 2008.

${ }^{94}$ Francisco Herreros, Del gobierno del pueblo a la rebelión popular (Santiago: Editorial Siglo XXI, 2003), p. 468. This assembly included the Christian Democrats in a Private Political Committee representing the political parties. A Private Social Committee brought together the various social movements.

95 Research paper, 'The Chilean Communist Party and its Allies: Intentions, Capabilities and Prospects', May 1986, Box 91703, Flower, Ludlow 'Kim' Files, RRL.

${ }_{96}^{6}$ FOIA, CIA Terrorism Review, June 1986.

97 FOIA, NID, 'Terrorism', February 1986; CIA report 'Pinochet and the Military', April 1987. 
linear development of the military task made such an outcome seem increasingly less far-fetched.

However, while the Communists were seeking to build upon the growth in opposition unity and mobilisation they knew that they did not yet have the military equipment necessary to guarantee the 'conquest of freedom' envisioned in their planned national uprising, and two key operations were thus set in motion to ensure both the military and political conditions necessary to guarantee the success of the uprising. ${ }^{98}$ Both operations began to be planned in early 1985 and together with increasing opposition unity and levels of social protest they set the stage for 1986 to become the decisive year in the confrontation with the Pinochet regime.

The first operation was the smuggling of nearly roo tons of weapons, explosives and ammunition into Chile in two shipments in early and mid-1986. The arms would be enough to equip an uprising and seize more weapons from the regime itself. The arms smuggling was under the control of the Communist Party's external logistics apparatus in cooperation with the Soviet, Vietnamese and Cuban governments, who provided the funding as well as the weapons themselves. ${ }^{99}$ The complex operation took months of preparation. The weapons were to be brought by sea from Cuba to the northern coast of Chile, where they would be transhipped in international waters and then transported to secret caches in abandoned mines near the landing point at Carrizal Bajo. A first effort in late 1985 failed, but another shipment in May I 986 was successful, landing some 40 tons of weapons and equipment. A second successful shipment was carried out in August I 986 before the operation was accidentally discovered by Pinochet's secret police. ${ }^{\text {I0o }}$

The second operation was the assassination of Pinochet. Although one had been in the pipeline since early I 985 , by 1986 an atentado had a clearer political purpose to terminally destabilise a regime tottering from successive and lengthening social protests. It was also hoped that the assassination would spark the long-awaited national uprising. The preparations took months, but finally the group of combatants was ready and the operation set for 7 September 1986.

${ }^{98}$ In a manifesto broadcast to Chile in February 1986 the party stated 'freedom has to be conquered, it is not a gift'. Chilean Communist Party Manifesto for 1986, 2 I Feb. 1986, USSR International Affairs: Latin America and Caribbean, Folder (376000-379999), RRL.

99 Rojas Nuñez, De la rebelión popular a la sublevación imaginada, p. 347.

${ }_{100}$ Chilean security forces eventually recovered over 3,000 M-1 6 rifles with nearly 2 million rounds of ammunition, I 02 FAL rifles, 6 M-60 machine guns, I I 4 RPG-7 grenade launchers with nearly 2,000 rockets, I67 LAW rocket launchers, nearly 2,000 hand grenades, over 2 tons of TNT and nearly is tons of $\mathrm{T}_{-4}$ as well as blasting caps and other equipment. Cable, US Embassy in Chile, 25 August 1986, Chile Folder 1986 (7), Box 91 I 8 I, LAAD, NSC Records, RRL. 
However, by the time the operation took place the political context had changed. The first of the planned protests had taken place on 2 and 3 July 1986. Despite months of regime preparations and an unprecedented deployment of force, the opposition's national strike paralysed the country and the regime lost control of much of Santiago's periphery. Eight people were killed and dozens wounded. The scale and violence of the protest demonstrated the enormous strength of anti-regime sentiment. The Christian Democrat president of the AC called it the largest protest since 1973 and 'the beginning of the beginning' of the efforts to topple the regime. ${ }^{\text {Ior }}$ The combination of regime repression, opposition unity, mass protests and antiregime violence showed that the struggle in Chile had the potential to overthrow the regime, especially if the protests followed the planned monthly schedule. This renewed fears of an uncontrolled transition among the more conservative elements of the opposition.

These conservatives were mainly active in the leadership of the PDC, men who had actively helped to bring down Allende in the expectation that power would be handed to them. When this did not happen, they moved to oppose the military regime but they remained deeply hostile to the Left and to autonomous social movements. Throughout the $1982-1986$ period these leaders had been struggling with the left-wing of the PDC, and within the opposition as a whole, jostling to control its direction and constantly seeking to minimise the social struggle, with the assistance of the United States and its international allies after 1984. However, these efforts were consistently stymied by Pinochet's refusal to negotiate. This was soon to change.

Shortly after the July protests, the State Department's Bob Gelbard travelled to Chile, ostensibly to investigate the circumstances in which a young Chilean-American was killed, but he also met with members of the military Junta (although not Pinochet) and various ministers on I 4 July. In his messages to them and to Chilean society more broadly, he urged Chile not to delay its transition, and he expressed his concerns regarding a 'process of polarisation and radicalisation that it is impossible to say where it is going, and which should end.' ${ }^{\circ 2}$ Gelbard also met with moderate opposition leaders, whom he told in no uncertain terms should end their cooperation with the Communists. ${ }^{103}$ Gradually, the leaders of the moderate opposition began to change their position, distancing themselves from the Communists and social protests. To justify their policy shift, the leaders of the minimalist

10 1 'Chile Authorities Act to Prosecute Leaders of Strike', The New York Times, 3 July 1 986 ; ' 3 Chilean Rebels Die During Police Raid', The Los Angeles Times, 2 July 1986.

${ }^{102}$ Quoted in the Vicaría de la Solidaridad July 1986 Monthly Synthesis, available at www. archivovicaria.cl/archivos/VS4cdo2b5bc5eff_02 I I 2010 I 2 I 6 pm.pdf.

${ }^{103}$ Corvalán, De lo vivido y lo peleado, p. 293. Corvalán bases his testimony on his contacts within the PDC and PS leadership. 
sectors began arguing that the social mobilisations had failed and were counterproductive (which they were if the goal was a negotiated transition that preserved the 1980 constitution). By August 1986, the AC was to all intents and purposes, dead. The discovery of the Carrizal arms caches was merely a subsequent confirmation to these conservatives that the Communists had planned for revolution. The protests and the escalating military actions had proved too successful, providing the incentive for an alliance between opposition minimalists and the regime.

Meanwhile the preparations for the assassination were already far advanced and it must have been tempting to think that Pinochet's killing might yet spark an uprising, seize the initiative back from the moderate politicians and destabilise the regime at a key time. The attempt was given the green light but it became something of a gamble. In the event, Pinochet's convoy was ambushed and although his bodyguards were killed or wounded the dictator survived. The ambush group escaped unharmed but the assassination attempt had failed and with it the Communist Party's military efforts to overthrow the dictatorship reached their apogee.

While some within the US intelligence agencies subsequently believed that the chances of an insurrection were slim, the White House took the threat seriously, with the CIA's Robert Gates outlining in a November National Security Council meeting the four main threats to a US-preferred transition: Pinochet's determination to stay in power, the threat of 'terrorist violence', 'external subversion' and the 'inability of the moderate opposition to coalesce together'. ${ }^{104}$ In effect there were two threats, insurrection and lack of unity within the 'moderate opposition'. With Pinochet imposing a state of siege and cracking down once more, the Reagan administration began to adopt a harder stance towards the dictator while continuing to lean on the opposition to exclude the Left. As happened in the early I 980 s, the trigger was the Left's resistance.

\section{Conclusion}

The history of the Left's military policy during the dictatorship is an integral part of the history of the transition. Across the Left, the military policy was seen as part of a much broader mass social struggle, and its subsequent development was a reaction to the violence of dictatorship rather than a natural outcome of their ideology. It was, to an extent, a reflection of the political-military violence unleashed against the Allende government. The armed resistance did not end in 1986 , but in 1987 the FPMR split and the Left's main military actors then became the 'autonomous' FPMR and some smaller left-wing ${ }^{104}$ Minutes of NSC meeting, I 8 Nov. 1986, Box 91 304 [Chile], Exec secretariat NSC, NSC meeting files, RRL. 


\section{I 8 Victor Figueroa Clark}

groups. None of them was able to sustain the level of activity of the PC-FPMR combination and they ended their actions in the early i 990 .

With much of the centrist opposition, the Chilean elite and the Reagan administration fearing a return to Marxist government, the revolutionary potential eventually achieved by the Left's mass resistance was an important factor conditioning the transition. After two years of armed actions and four years of mobilisations, some CIA analysts suggested that Pinochet's ability to remain in power largely depended on the support of the military, a view apparently shared by senior Chilean officers. ${ }^{105}$ The regime was forced to rely heavily on coercion to sustain itself, yet as a CIA paper from early i 986 noted, the military had 'great difficulty curbing slum violence' and had failed to stop the bombing campaign. ${ }^{106}$ At the same time, repression had a negative impact on military morale, a Chilean general visiting Washington told officials that many younger army officers were beginning to resent putting down protests, and that they were beginning to question Pinochet's wisdom in resisting a transition. ${ }^{107} \mathrm{~A} \quad 1987$ CIA report also indicated that Pinochet's relationship with the officer corps worsened from 1984 onwards as they were increasingly forced to shoulder a brutal internal security mission the Carabineros could no longer fulfil alone. ${ }^{108}$ Assuming that US sources in the Chilean military accurately reflected reality, the armed resistance created substantial practical and psychological problems for the regime's most important institution.

The regime justified its existence through the defeat of 'communism', economic growth and the provision of order following the chaos of the Allende years. These 'pillars' of its self-legitimation were seriously damaged by severe economic crisis and international isolation, while mass mobilisations and armed actions destroyed the sense of social 'order'. ${ }^{\circ}{ }^{\circ}$ 'This is why the communists' military policy had a substantial political impact. Then the discovery of the Carrizal arms caches and the attempt on Pinochet's life 'shocked the armed forces into recognising that the violence-prone Left is a real threat to the regime'. This pushed members of the Junta to seek a rapprochement with the centre-right opposition; with the same report stating 'we believe the junta members were motivated partly by concern over recent communist efforts to destabilise Chile.' r $о$ 'The final blows of the PC's military policy thus

105 Confidential Intelligence Research Report, 23 July 1986, Folder Chile Documents, Box 9I I 8 I, LAAD, NSC Records, RRL.

${ }^{106}$ FOIA, CIA Research Paper 'The Chilean CP and its Allies', May 1986.

107 Memo, Tillman to Pointdexter re Luncheon, i6 May 1986, Folder Chile I986 (I), Box 9 I 8 I, LAAD, NSC Records, RRL. Other motives for military discontent are also detailed in Loveman, Chile, pp. 300-I.

${ }^{108}$ FOIA, CIA report, 'Pinochet and the Military', April 1987.

${ }^{109}$ Huneeus, El régimen de Pinochet, pp. 21 4-1 5.

Iо FOIA, CIA report, 'Pinochet and the Military', April 1987. 
helped to convince the regime's top brass that the Americans were right. A managed transition was necessary to avoid either a costly civil war or a disastrous revolution.

Yet the failures of the two big operations of 1986 , and the ensuing changes to the political situation also provided ammunition for those within the PC who opposed the military elements of the policy of rebellion. From October 1986, these elements of the Party's work were restructured, key commanders removed or replaced under the guise of improving its functioning, but in reality the military task was being reined in. ${ }^{11}$ T The Communists returned to the hope that a broad political coalition would insist on Pinochet being ousted and be followed by an emergency consensus government and elections. ${ }^{12}$ Unfortunately for the PC, the armed resistance and the spectre of the Popular Unity created the basis for agreement between the regime, its moderate opponents and Washington. They were excluded from the negotiations a priori, and they voluntarily withdrew their only remaining form of leverage.

The shutdown of the military task also fitted in with changes in the international situation, with the Soviet Union's new international policy emphasising cooperation and reducing tensions with the West. While support for the PC and the Almeyda PS continued, according to US intelligence sources, pressure was applied for both to return to their more traditional forms of struggle. ${ }^{113}$ After 1986, as Gorbachev and Shevardnadze took more direct control of foreign policy, Latin America slipped down the Soviet list of priorities and material support for insurgents became more problematic. ${ }^{14}$ That the Soviets agreed with abandoning the armed elements of struggle strengthened the convictions of a leadership that had never been united or deeply convinced of its revolutionary potential. ${ }^{15}$

The Pinochet regime initially sought a transition that would consolidate authoritarianism. The Left's armed resistance played an important role in derailing this project, creating a tense dynamic between those in the regime who perceived a need to speed up the transition schedule that had been outlined in I980, and expand its purpose, and those who, like Pinochet, thought it ought to be delayed and minimised. The Left's armed resistance combined with mass mobilisations to remind US policymakers of Nicaragua in 1979

${ }^{11}$ Interview with Salvador.

${ }_{112}$ A 1986 interview with PC leader José Sanfuentes cited in Herreros, Del gobierno del pueblo a la rebelión popular, p. $47 \mathrm{I}$.

${ }^{113}$ CIA report 'Opposition to Chilean Government', Oct. 1987, Folder Chile, the Communist Party and the Left, Box 91 528, Flower, Ludlow 'Kim' Files, RRL.

${ }^{114}$ Anatoly Dobrynin, In Confidence (New York: Random House, 1995), p. 622; Svetlana Savranskaya, 'Gorbacher and the Third World', in Sergei Radchenko and Artemy Kalinovsky (eds.), The End of the Cold War and the Third World (Oxford: Routledge, 20II), pp. 28-30.

II Rojas Nuñez, De la rebelión popular a la sublevación imaginada, p. 32 I. 


\section{Victor Figueroa Clark}

and thus created the conditions that led the Reagan administration to support a transition to civilian rule in Chile. In response to armed forms of resistance, the transition became, in significant part, a counter-insurgent project that aimed specifically at avoiding a revolutionary outcome.

Yet the Left's resistance played a contradictory role. The same tactics that were successful in stimulating mass pressures for change in the early to midI 980 s also created elite and international level pressures for compromise. These combined with changes in the international situation and in Chilean society in the late 1980 s to create a combination that the Left could not defeat. Yet the resistance did reshape the way short and long-term interests were perceived in the US, among regime supporters and in the moderate opposition. The fact remains that the Left's armed resistance was not defeated or contained. Far from being irrelevant or counter-productive, the Left's active forms of resistance and use of 'acute violence' played an important role in shaping the Chilean transition even if it was unable to overthrow Pinochet or effectively condition the post-dictatorship regime.

\section{Spanish and Portuguese abstracts}

Spanish abstract. La historia de la transición hacia gobiernos civiles en Chile en buena parte pasa por alto y marginaliza el papel de formas de resistencia confrontacionales y armados contra la dictadura. Este artículo rastrea la historia de las actitudes y experiencias de la izquierda chilena hacia la violencia antes y después del golpe, y evalúa los efectos de su incorporación en la lucha en contra de la dictadura sobre el régimen y la administración Reagan. Concluye que la resistencia armada fue un factor importante en determinar la política norteamericana hacia Chile durante los años 80 , y por lo tanto jugó un papel importante en la transición en general.

Spanish keywords: Chile, dictadura, resistencia, comunista, socialista, transición

Portuguese abstract. A história da transição da ditadura para o governo civil no Chile negligencia, ou marginaliza, o papel das formas armadas e conflitivas de resistência ao regime. Este artigo delineia a história do engajamento da esquerda com formas armadas de luta antes e após o golpe, além de avaliar os efeitos que sua inserção no embate contra a ditadura teve sobre o regime chileno e o governo Reagan. Conclui-se que a resistência armada foi um fator de grande importância na determinação da política americana com relação ao Chile na década de 1980, desempenhando assim um papel importante na transição como um todo.

Portuguese keywords: Chile, ditadura, resistência, comunista, socialista, transição 